\title{
Effect of Current on Mechanical Properties and Microstructure of Aluminum 6061 with Gas Tungsten Arc Welding Process
}

\author{
$\operatorname{Tarmizi}^{11^{*}}$, Kevin Daniel Sianturi'2), Irfan $^{1)}$ \\ ${ }^{1)}$ Metal Industries Development Center (MIDC), Ministry of Industry, Bandung 40135, Indonesia \\ 2) Department of Metallurgical Engineering, Faculty of Engineering, University of Jenderal Achmad Yani, Bandung 40285, Indonesia \\ *) Corresponding Author : tarmizi@kemenperin.go.id
}

\section{Article Info}

\section{Keywords:}

Gas Tungsten Arc Welding,

Aluminum 6061,

Flow,

Tensile Strength.

\section{Article history:}

Received: $12 / 05 / 20$

Last revised: 11/09/20

Accepted: 01/10/20

Available online: $31 / 10 / 20$

DOI:

https://doi.org/10.14710/kapal. v17i3.30054

\section{Abstract}

Aluminum 6061 is an aluminum alloy that is widely used in various industrial fields, which heat treatable. However, it can be joined using a welding process. Aluminum joining using the Gas Tungsten Arc Welding (GTAW) process has become the option to produce good quality joints. This research aims to get optimum welding parameters by knowing the mechanical properties and microstructure of the welding results. The GTAW process uses a 25 -volt voltage, Argon protective gas flow rate of 15 liters per minute with filler rod ER 5356 with $2.4 \mathrm{~mm}$ diameter and electrodes tungsten $2.4 \mathrm{~mm}$ in diameter. This process uses a single $\mathrm{V}$ butt joint and groove angle of $60^{\circ}$ with variations in the current of 100,110 and $120 \mathrm{~A}$. The results indicate that specimens with a variety of current of $110 \mathrm{~A}$ give better results in the absence of defects, have a tensile strength of $152 \mathrm{MPa}$, and get a hardness value of $87.55 \mathrm{HV}$, which is the highest compared to the other two specimens. Whereas specimens with the current variation of 100 and 120 A have defects in the weld area. The optimum parameters of the 6061 aluminum GTAW process with a thickness of $6 \mathrm{~mm}$ using a current of $110 \mathrm{~A}$ bring on better outcomes and mechanical properties than the use of currents of 100 and $120 \mathrm{~A}$.

Copyright (C 2020 KAPAL : Jurnal Ilmu Pengetahuan dan Teknologi Kelautan. This is an open access article under the CC BY-SA license (https://creativecommons.org/licenses/by-sa/4.0/).

\section{Introduction}

In production technology using metal raw materials, welding is a workmanship process that plays a very important role [1]. The industry's development now makes welding technology develop rapidly along with the needs of the industrial world to produce good products, especially using metals as raw materials in the production process. Welding technology is beneficial in both simple construction and construction works that have difficulty and high requirements.

Welding is a highly needed field by the industrial, both the manufacturing industry and the fabrication industry. The shipping industry, general engineering and other fields make the welding process a major factor for getting good quality weld joints [2]. To produce welding products with good quality joints and acceptance criteria visually and measuring and testing the welds and microstructure observation [3].

Many stages must be fully considered to get the optimal results using welding in the joint process of metals, starting from the design stage until the stages of workmanship and inspection. The design stages include selecting the welding process, the choice of the groove angle used, and more. These work stages include the use of appropriate currents and welding positions, as the inspection includes mechanical testing and microstructure observation [4].

Aluminum and its alloys are metals that are widely used by engineering because they have various advantages, including lightweight, good formability, relatively good tensile strength, corrosion resistance, and mechanical properties that can be improved by cold working or heat treatment and has weldability that varies depending on the type of alloy. Aluminum alloys have heat-treatable alloys and non-heat-treatable alloys [3].

The use of aluminum continues to grow in various transportation industries such as the car, train, ship, and aerospace industries [5], [6], [7], [8]. Research by Fortain and Gadrey [9] shows that the main use of aluminum in the transportation industry $27 \%$, construction $20 \%$, packaging $16 \%$, electricity $10 \%$, machinery and equipment $8 \%$ sectors related to sustainable products (7\%) where exceptional growth reaching 60 million tons by 2020 has been predicted. J.M. Fortain and S. Gadrey. 
Aluminum is a metal with a high corrosion resistance compared to steel and iron due to the formation of a protective layer due to the reaction of metals to air so that the aluminum protects from corrosion. Aluminum alloy has a weld metal ductility value that tends to be smaller than parent metal than the weld metal ductility value of steel. In the shipping, aluminum 6061 is widely used as a construction frame material such as a frame in stiffener construction, which means construction in offshore buildings. This aluminum series is the best suited for construction, especially shipping construction, due to its ductility, formability when forged, and corrosion-resistant [10].

Tungsten Inert Gas (TIG), also known as Tungsten Arc Welding (GTAW), is a welding process using heat from an electric arc produced between a tungsten electrode and a parent metal as shown in Figure 1. Argon gas is used as a shield from outside air influence so that it does not produce slag and free from welding spatter [11], [12]. Electrodes use tungsten rods that can produce electric arcs without melting. When needed, filler metals shaped consumable wires can be added externally to the arc [13]. The speed of feeding the filler metal can be adjusted regardless of the amount of electric current so that the penetration of the welding will be well controlled. This arrangement allows TIG welding to be suitable for both thin and thick plates [14].

The Gas Tungsten Arc Welding (GTAW) process is one of the methods used to weld aluminum because it is easy to apply, inexpensive, and produces high-quality joint [13].

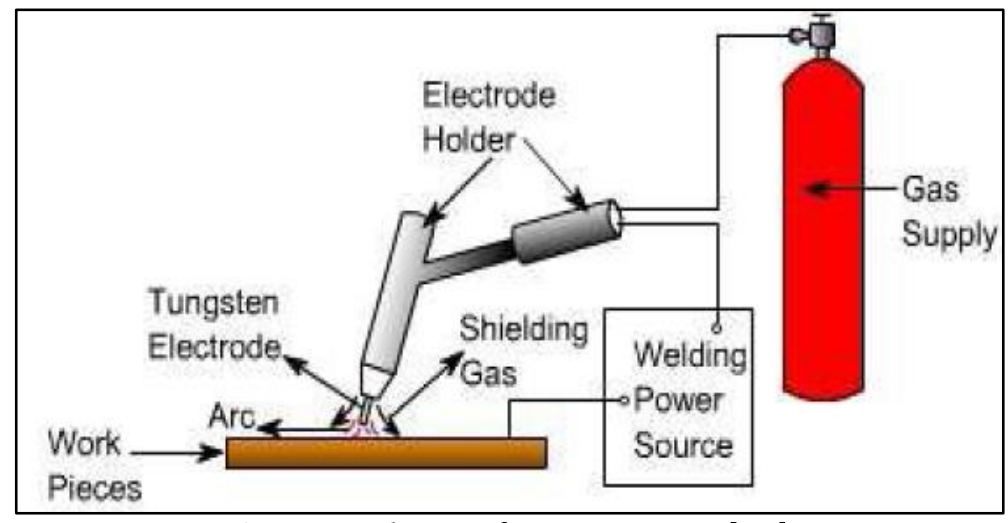

Figure 1. Scheme of GTAW Process [15].

The aluminum 6061 joint process is often carried out by imposing the GTAW or GMAW process because it is much easier and economical [16]. The use of the GTAW process in welding aluminum and its alloys is based on penetration into weld grooves or fissures, which can be regulated, so that the quality and quality of welds can be improved [12]. However, the GTAW process still has its challenges and risks of welding defects in the form of surface or sub-surface cracks, undercut, porosity, or subsurface inclusions [17]. The occurrence of hot cracking and softening in the welding area and HAZ are becoming a major problem in welding aluminum [16], [18].

Several studies related to aluminum welding's mechanical properties using the GTAW process have been carried out, such as research conducted by Lakshman Singh et al. [19] on aluminum 5083 showed that an increase in tensile strength as the welding speed increases to the optimum speed and then decreases. C.W.'s research Mohd Noor et al. [20] showed that an increase in welding current would increase heat input, and the possibility of defects forming also increased. Besides, high welding currents also reduce the yield strength, tensile strength, and toughness value of the aluminum alloy 5083. Experimental results C Prabaharan et al. [21] concluded that an increase in welding current and gas flow rate would increase the weld deposit area while increasing the voltage would reduce the weld deposit area. When all other welding parameters are held constant, increasing current will increase the weld penetration depth and width and the size of the weld bead. Whereas weld penetration is more influenced by welding speed than variables other than current. If the welding speed is slow, the heat input speed increases so that the weld width and weld height are also increased [15]. The study of Mayur. S et al [22] showed an increase in hardness and refinement of grain in the weld area with increasing the welding current used.

This research using the current variation to weld aluminum 6061 with filler metal 5356 using the GTAW process. This research aims to joint aluminum 6061 using the GTAW process with current variations to get the best joint and determine the joint results' mechanical properties, microstructure analysis of the GTAW process results, and the exact current on the welding of aluminum 6061. The metal jointed is aluminum 6061 with a thickness of $6 \mathrm{~mm}$ using a current variation of $100 \mathrm{~A}$, $110 \mathrm{~A}$, and $120 \mathrm{~A}$.

Some of the parameters that influence the GTAW process are [23]: 1) Currents. The welding current is the most influential variable in the arc welding process, which will control the electrode combustion rate, fusion depth, and weld geometry. The Current influences the shape of the weld bead, welding speed, and welding quality. Most GTAW processes use direct current at negative electrodes (direct polarity) because they produce better weld penetration depth and higher welding speeds than positive electrodes (reverse polarity). 2) Electric voltage. Electric voltage has a difference in electrical potential between the tip of the welding wire and the weld pool liquid's surface. The welding voltage can be fixed or adjusted depending on the welding equipment. The voltage will determine the shape of the fusion zone and the height of the weld. 3) Welding speed. Welding speed is the electrode rate at which the arc is moved alongside the welding joint. The welding speed is an important parameter that will affect the heat input in the GTAW process. 4) Heat Input. Heat input is a relative measure of energy transferred per unit length of the weld. The higher the heat input, the slower of cooling rate. Conversely, the lower heat input, the faster of cooling rate. Therefore, such as preheating and interpass temperature, heat input is an important characteristic that affects the cooling rate, which can affect the mechanical properties and microstructure of weld metal and HAZ. 5) Protective gas. Protective gases are used in GTAW to prevent welding metal contamination from the 
atmosphere. This contamination can produce porosity, weld cracks, and even changes in the liquid metal's chemical composition. Besides that, the protective gas also has a big influence on the stability of the electric arc. 6) Metal filler. The filler metal is generally used for plate thicknesses above $2 \mathrm{~mm}$, has a chemical composition similar to that of the parent metal. Filler diameters are between 1.6 and $3.2 \mathrm{~mm}$, and automatic systems are usually at room temperature of the coil.

The advantages of the GTAW process include: i) produce high-quality welding joints with low distortion ii) free from welding sparks \& slags iii) use with or without filler metals iv) weld almost all metals v) allow independent control of heat sources or filler addition metal vi) make it possible to control variable or welding parameters accurately [15].

Aluminum 6061 is a type of aluminum-magnesium-silicon alloy. Al 6XXX series aluminum alloy is a type of aluminum that can be heat-treatable. Alloys in this system have lower strength than other alloys but are very ductile with excellent formability for forging. Besides, the Al 6XXX series is very sensitive to heat cracking yet has good corrosion resistant properties. Aluminum 6061 is classified as a metal that is quite difficult to weld. It also includes in the heat-treatable category, which means it can be strengthened by mechanical working and precipitation hardening [24].

\section{Methods}

The welding process of aluminum 6061 with a $300 \mathrm{~mm}$ x $120 \mathrm{~mm}$ and a thickness of $6 \mathrm{~mm}$ is carried out at the Metal Industries Development Center using a GTAW machine. The GTAW process uses a 25 Volt voltage and Argon protective gas flow rate of 15 liters per minute with a strong current variation of $100 \mathrm{~A}, 110 \mathrm{~A}, 120 \mathrm{~A}$. The electrodes used are $2.4 \mathrm{~mm}$ diameter tungsten. The filler rod used in this study was ER 5356, with a diameter of $2.4 \mathrm{~mm}$. The 6061 aluminum welding uses a single $\mathrm{V}$ butt joint type joint with two passes and a groove angle of $60^{\circ}$. After visual testing, radiographic $\mathrm{X}$-ray testing is carried out using an Eresco MF4 model machine with $120 \mathrm{kV}$ power and $4.5 \mathrm{~mA}$ current for 1 minute and using a $4 \mathrm{x} 10$ inch film to check any indications defects in the test specimen. This radiography uses a Single Wall Single Image (SWSI) beam illumination technique.

After that, the metallographic test begins with cutting the specimen, mounting, then sanding until it becomes delicate using sandpaper number 5000 and polishing before dipping it into the Keller's reagent etching solution to check the weld area and its surroundings both in macro and micro application using an optical microscope. Hardness measurements are made at 3 points in each area, and the experiment gap is $0.02 \mathrm{~mm}$ using Vicker's micro method with a load of 200 gf for 5 seconds. Sampling for tensile test refers to the AWS D1.2 standard with two test specimens for each current variation. The test results obtained are then processed for analysis and conclusions following the objectives of this research.

\section{Results and Discussion}

\subsection{Visual Analysis of Welding Results}

The test results of the 6061 aluminum GTAW process refer to the AWS D1.2 standard. Visual testing shows that the aluminum 6061 GTAW process is well jointed. The face and root sides look unified and are well connected for variations in currents of $100 \mathrm{~A}, 110 \mathrm{~A}$, and $120 \mathrm{~A}$. The overall experimental results look good visually and can be accepted to be continued with other tests, as shown in Figure 2.

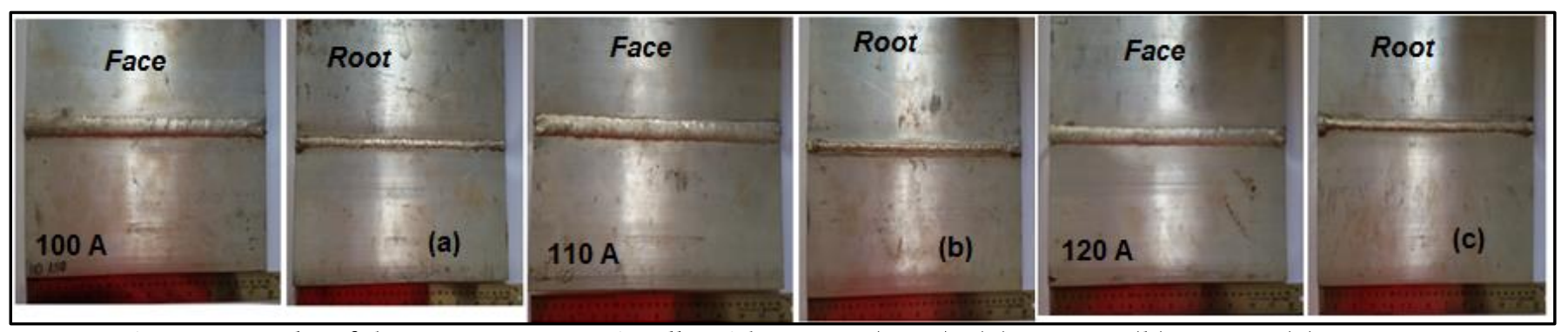

Figure 2. Results of the GTAW Process Visually with Current (Amp) : (a) I =100 A, (b) I=110 A, (c) I = 120 A.

\subsection{Analysis of Radiographic Examination}

After the visual testing, then radiographic testing is performed and the results are shown in Figure 3. This radiographic test uses an ERESCO MF4 machine with sources from separate X-ray rays. In radiographic testing, there is an indication of porosity defects in welds using $100 \mathrm{~A}$ and 120 A currents. 

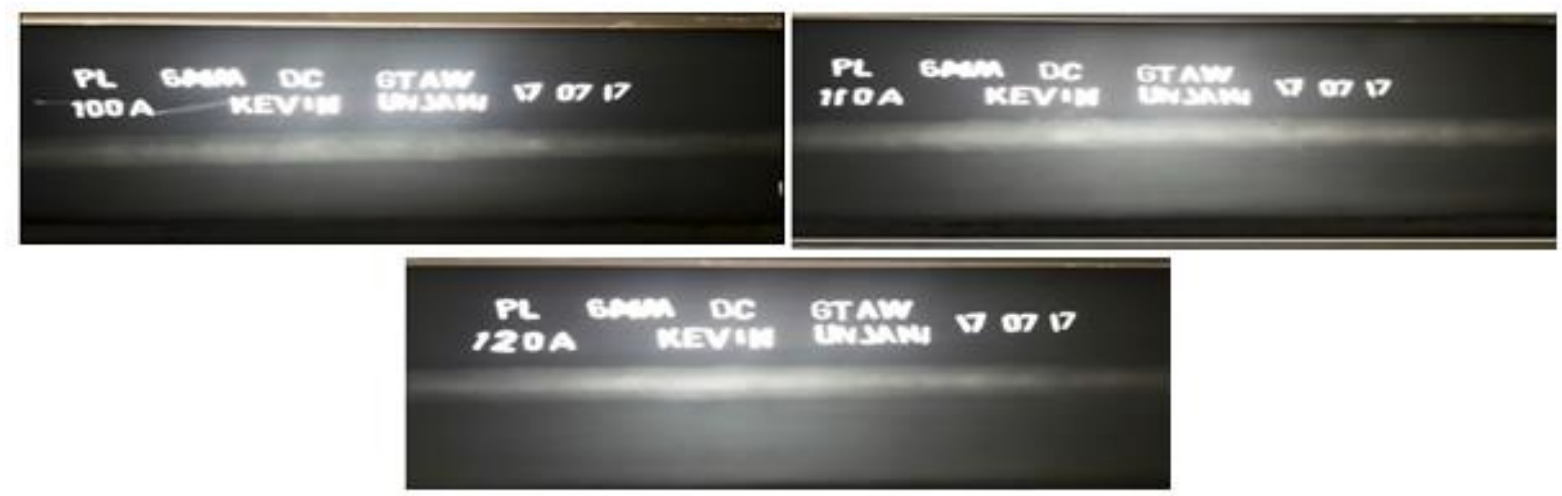

Figure 3. Radiographic Test Results of the GTAW Process with Current (Amp) I =100 A, $110 \mathrm{~A}$, and $120 \mathrm{~A}$.

\subsection{Analysis of Defects and Macrostructures}

The results of the macro structure test show the area of gas tungsten arc welding weld like weld metal, fusion weld, and heat affected zone as in Figure 4. The It also shows the porosity defects in the joint results using currents of $100 \mathrm{~A}$ and $120 \mathrm{~A}$ and this is following the results of the previous radiographic tests. This porosity is caused by the diffusion of hydrogen during the welding process [25]. According to AWS D 1.2, [26] the greatest number of defects must not exceed $2 \mathrm{~mm}$, as long as $25 \mathrm{~mm}$ must not exceed $10 \mathrm{~mm}$.
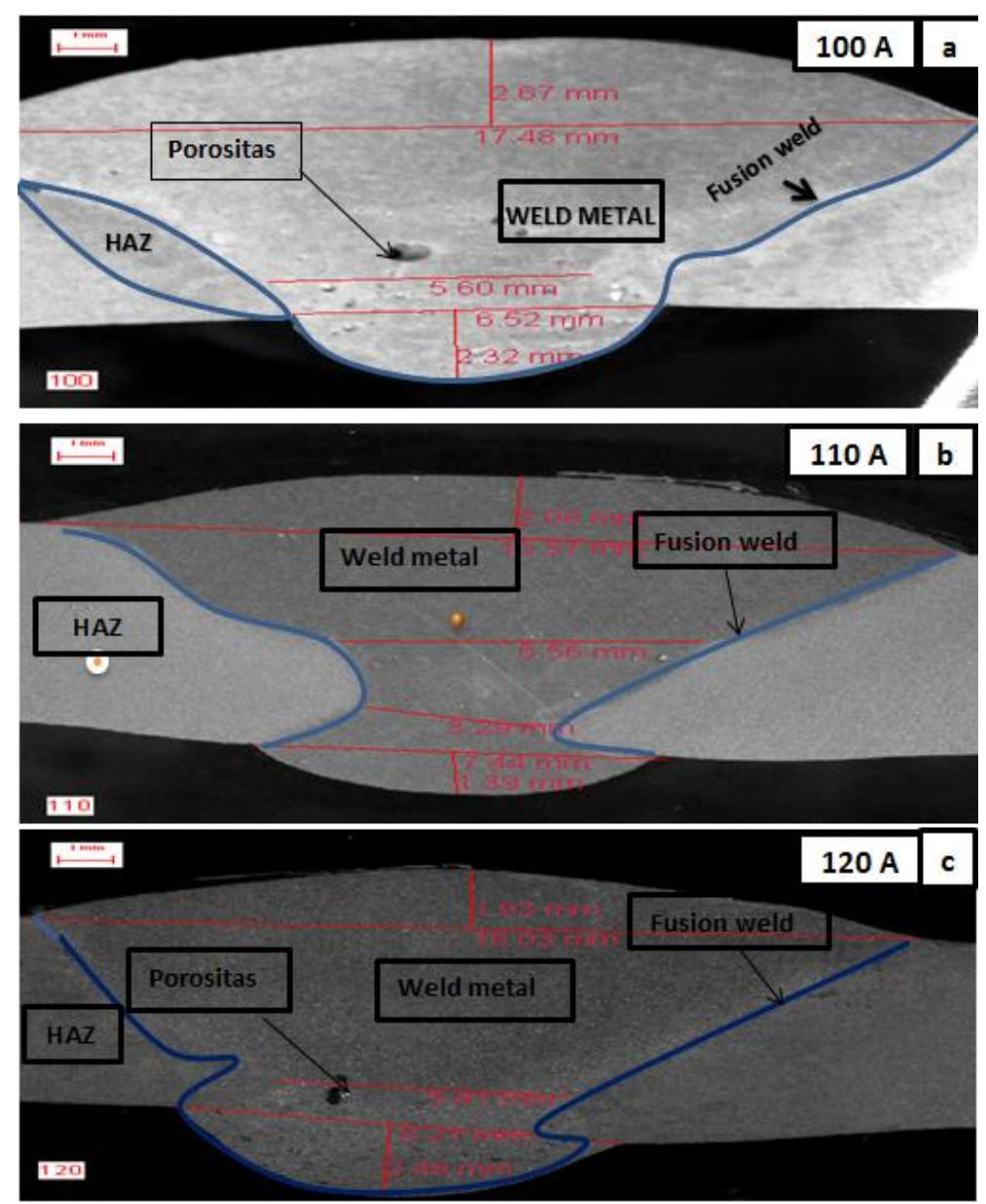

Figure 4. Macrostructure Examination with Current (Amp) : (a) I =100 A, (b) I=110 A, (c) I = $120 \mathrm{~A}$.

\subsection{Analysis of Tensile Test}

Figure 5 shows the result of the tensile test of the aluminum joint 6061 according to the AWS D1.2 standard using current variations on the GTAW process. All test specimens fracture occurs in the base metal area and can be accepted in accordance with AWS D1.2. Figure 6 shows the tensile strength of a welded joint using a 110 A current of 152 Mpa with deviation standard SD1 $=56,66$ and SD2 $=53,67$, which is higher than the other two specimens with different current variations but lower than the tensile strength of base metal of $280 \mathrm{MPa}$. It occurs because of the effect of softening on aluminum during heating [27]. 

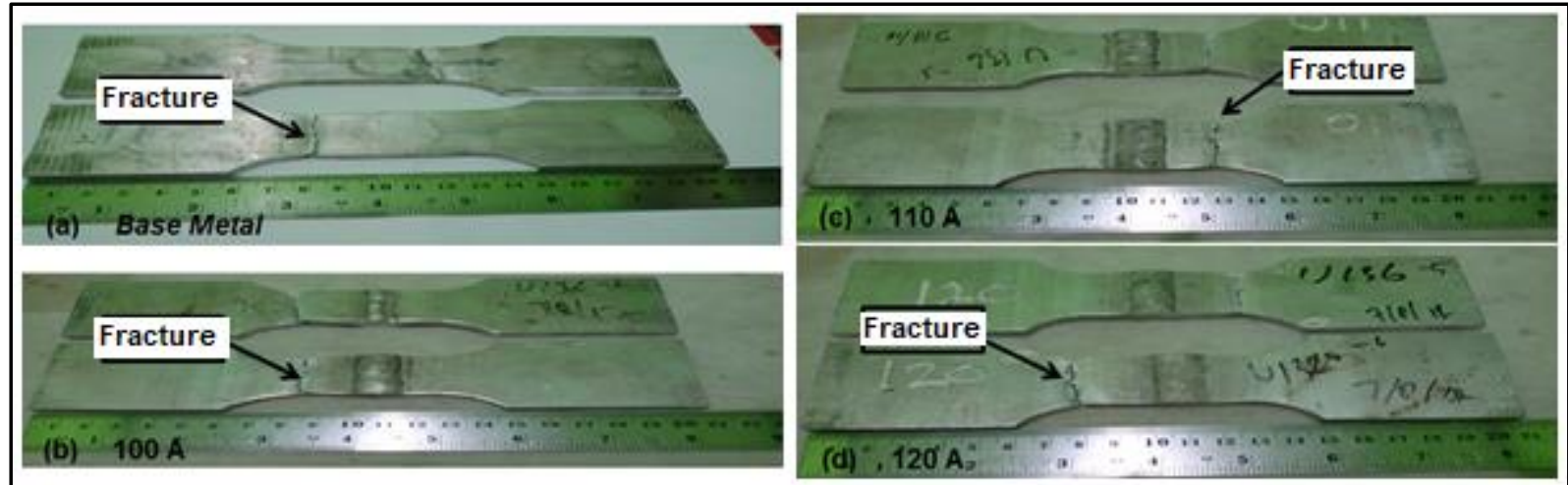

Figure 5. Fracture of Tensile Test Specimens with Current (Amp) : (a) I =100, (b) I=110, (c) I = 120.

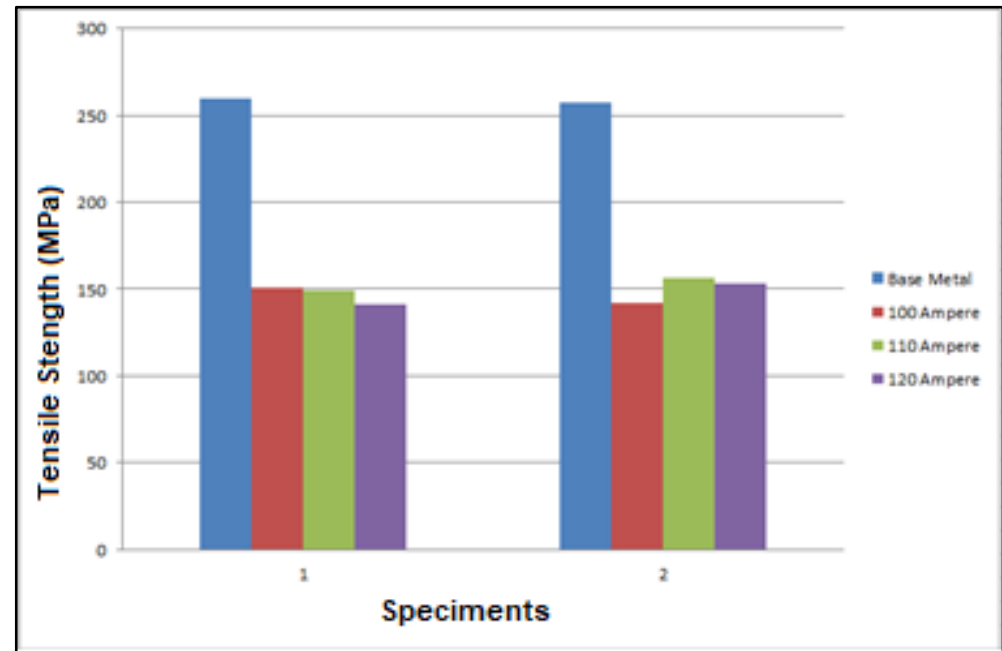

Figure 6. Tensile Test Results with SD1= 56,66 and SD2 = 53,67.

\subsection{Analysis of Microstructure Examination}

Based on Al alloy 6061 series's microstructure photographs, as shown in Figure 7, there are two different contrasts color. First is the dark color, as it refers to the reference obtained. The resulting dark color is the $\alpha$-AlFeSi phase, which is metaphase. It means that this phase can change if it gets a high enough temperature.

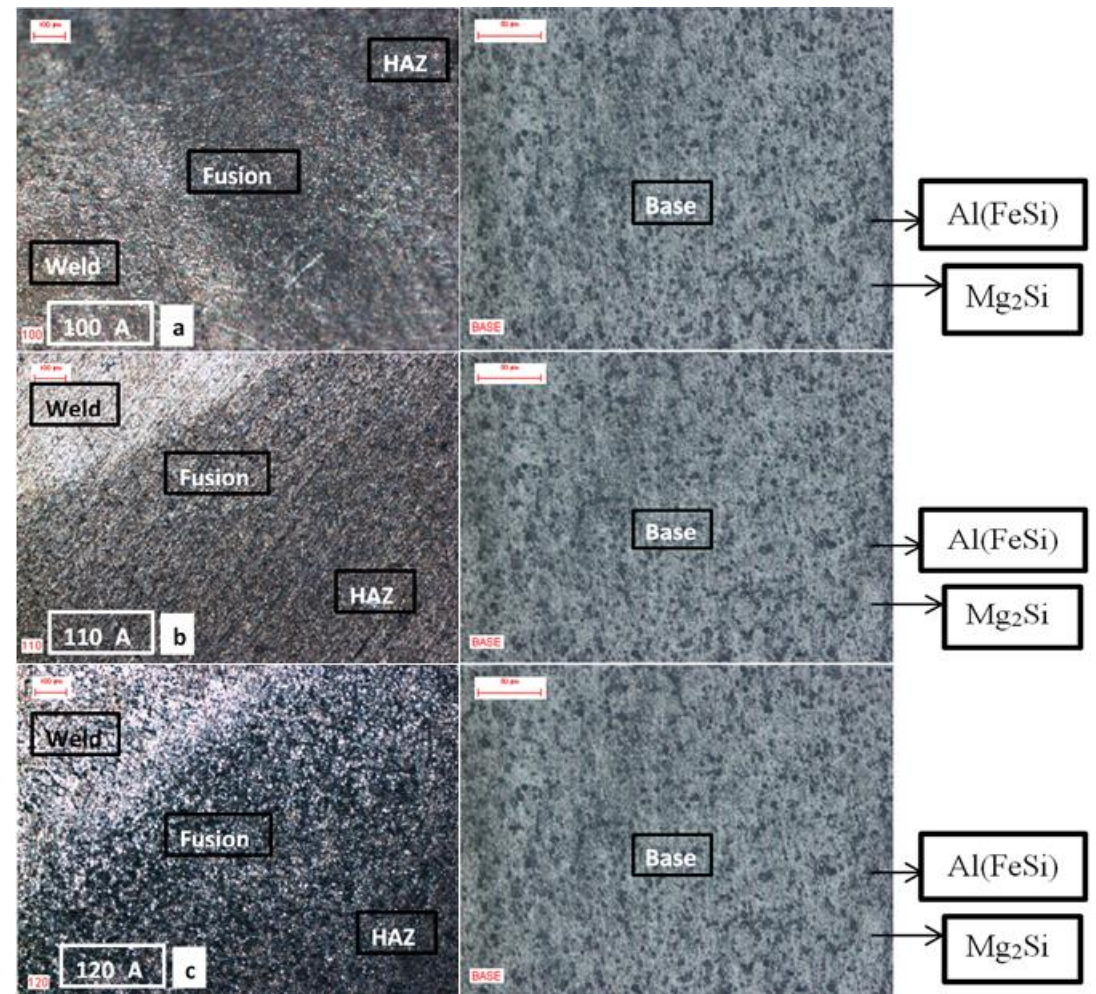

Figure 7. Microstructure Examination with Current (Amp) : (a) I =100 A, (b) I=110 A, (c) I = 120 A. 
The second is a bright white color when referring to the white color reference produced because using a Keller etching is Mg2Si. The use of an etching solution will affect the image of the microstructure produced [28]. The shape and size of the same grain (equiaxed) are also seen in the weld area after changing grain shape from the long flat during the welding process, and the second phase particles can also affect the strength and tenacity of the results of the welding process [29].

\subsection{Analysis of Hardness Test}

The next test is hardness testing using micro-hardness tests (micro Vickers), with the results shown in Figure 8. The most significant hardness test results are found on the weld metal. For hardness in the base metal area to be the smallest hardness than three other regions, namely HAZ, weld metal, and fusion weld. The highest hardness value for the weld area is $87.55 \mathrm{HV}$ using $110 \mathrm{~A}$ current variations, higher than the two specimen joint using $100 \mathrm{~A}$ and $120 \mathrm{~A}$ currents. The specimen's hardness value varies and is not linear for any increase in welding current due to differences in heat input during the GTAW process. Overall, the weld metal area contains the highest hardness value compared to other areas due to many grain boundaries and the existence of the Mg2Si phase formed during the welding process [30]. The microstructure's increased hardness is caused by the rapid cooling rate experienced in the welding area, which produces a super-saturated solid solution. During subsequent cooling and natural aging phenomena, very fine Mg2Si precipitate may have formed near the welding area [11].

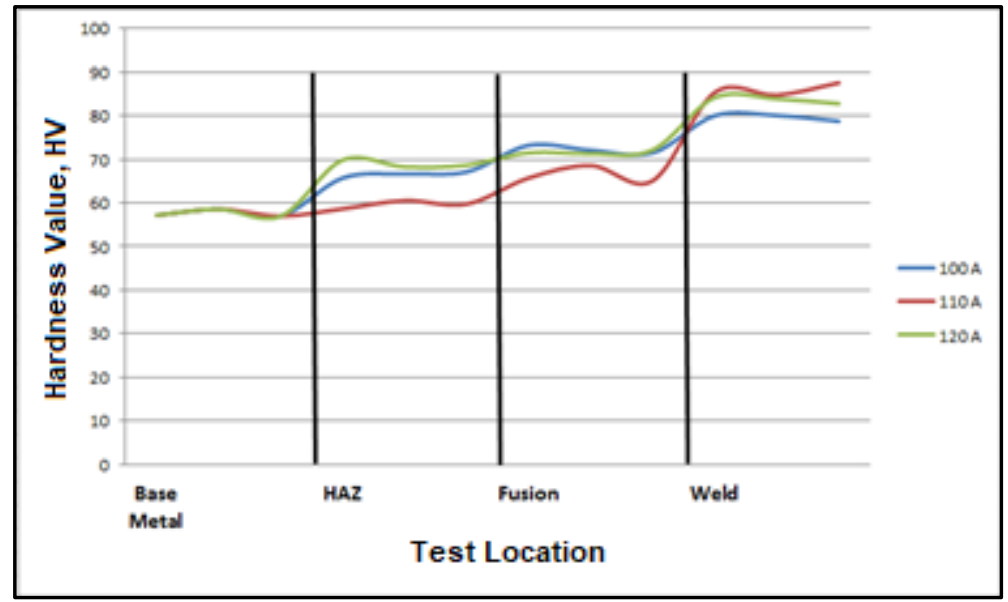

Figure 8. Distribution of Hardness

\section{Conclusion}

Aluminum 6061 metal joint with GTAW process using 25-volt voltage parameters, Argon protective gas flow rate of 15 liters per minute using ER 5356 filler rod $2.4 \mathrm{~mm}$ in diameter and $2.4 \mathrm{~mm}$ diameter tungsten electrode with single $\mathrm{V}$ butt joint type joint and $60^{\circ}$ groove angle were successfully well done. The test results show that $110 \mathrm{~A}$ current gives better results compared to the other two variations of current with a tensile strength of $152 \mathrm{MPa}$ and hardness of $87.55 \mathrm{HV}$ and no defects in the test specimen. The appropriate current in the GTAW process will provide welding results with good mechanical properties and microstructure.

\section{Acknowledgements}

The authors would like to acknowledge Dr. Ing. Ir. Supono Adi Dwiwanto, Staff of BBLM Machining and Welding Section who have provided both time and facilities for this research.

\section{References}

[1] A. Wibowo, N. P. Aryanto, C. B. Nugroho, and M. Ismail, "Pengaruh Frekuensi Pulse Pengelasan GTAW Pada Aluminium Alloy 6061," Jurnal Integrasi, vol. 11, no. 1, pp. 59-62, 2019.

[2] S. Jokosisworo, "Pengaruh Perbedaan Posisi Pengelasan Terhadap Kekuatan Sambungan T-Joint Pengelasan Fillet Dengan Las FCAW Pada Plat Mild Steel," KAPAL: Jurnal Ilmu Pengetahuan dan Teknologi Kelautan, vol. 7, no. 2, 2010.

[3] L. Andewi, "Pengaruh Variasi Arus Pada Hasil Pengelasan TIG (Tungsten Inert Gas) Terhadap Sifat Fisis Dan Mekanis Pada Alumunium 6061," Universitas Negeri Semarang, 2016.

[4] A. Naufal, S. Jokosisworo, and S. Samuel, "Pengaruh Kuat Arus Listrik Dan Sudut Kampuh V Terhadap Kekuatan Tarik Dan Tekuk Aluminium 5083 Pengelasan GTAW," Jurnal Teknik Perkapalan, vol. 4, no. 1, 2016.

[5] C. S. Jawalkar, S. Kant, and others, "A review on use of aluminium alloys in aircraft components," i-Manager's Journal on Material Science, vol. 3, no. 3, p. 33, 2015.

[6] H. M. Hajar, F. Zulkifli, M. G. Mohd Sabri, and W. B. Wan Nik, "Protection against corrosion of aluminum alloy in marine environment by lawsonia inermis," International Journal of Corrosion, vol. 2016, 2016.

[7] B. Ertuğ and L. C. Kumruoğlu, "5083 type Al-Mg and 6082 type Al-Mg-Si alloys for ship building," American Journal of Engineering Research, pp. 146-150, 2015. 
[8] P. Kula et al., "New possibilities of applications aluminium alloys in transport," Archives of Metallurgy and Materials, vol. 54, no. 4, pp. 1199-1205, 2009.

[9] J. M. Fortain and S. Gadrey, "How to select a suitable shielding gas to improve the performance of MIG and TIG welding of aluminium alloys," Welding International, vol. 27, no. 12, pp. 936-947, 2013.

[10] A. S. Prawira, S. Jokosisworo, and U. Budiarto, "Pengaruh Kuat Arus Listrik dan Travelling Speed terhadap Kekuatan Impact Alumunium 6061 Pengelasan Gas Tungsten Arc Welding (GTAW) dengan Gas Pelindung Argon," Jurnal Teknik Perkapalan, vol. 7, no. 4, 2019.

[11] P. Kumar, K. P. Kolhe, S. J. Morey, C. K. Datta, and others, "Process parameters optimization of an aluminium alloy with pulsed gas tungsten arc welding (GTAW) using gas mixtures," Materials Sciences and Applications, vol. 2, no. 04, p. 251, 2011.

[12] M. Arun and K. Ramachandran, "Effect of welding process on mechanical and metallurgical properties of AA6061 aluminium alloy lap joint," International Journal of Mechanical Engineering and Research, Research India Publications, vol. 5, no. 1, 2015.

[13] M. Dorta-Almenara and M. C. Capace, "Microstructure and mechanical properties of GTAW welded joints of AA6105 aluminum alloy," Revista Facultad de Ingeniería, vol. 25, no. 43, pp. 7-19, 2016.

[14] G. Pamungkas, "Pengaruh Variasi Kuat Arus Pengelasan Tungsten Inert Gas (TIG) Terhadap Kekuatan Tarik Dan Struktur Mikro Baja Karbon Medium," Universitas Lampung, 2016.

[15] A. Sarolkar and K. Kolhe, "A Review of (GTAW) Gas Tungsten Arc Welding and its Parameters for Joining Aluminium Alloy," International Journal for Science and Advance Research In Technology, vol. 3, no. 8, pp. 361-368, 2017.

[16] A. K. Lakshminarayanan, V. Balasubramanian, and K. Elangovan, "Effect of welding processes on tensile properties of AA6061 aluminium alloy joints," The International Journal of Advanced Manufacturing Technology, vol. 40, no. 3-4, pp. 286-296, 2009.

[17] M. W. Dewan, M. A. Wahab, and A. M. Okeil, "Influence of weld defects and postweld heat treatment of gas tungsten arc-welded AA-6061-T651 aluminum alloy," Journal of Manufacturing Science and Engineering, vol. 137, no. 5, 2015.

[18] Y. Liang, J. Shen, S. Hu, H. Wang, and J. Pang, "Effect of TIG current on microstructural and mechanical properties of 6061-T6 aluminium alloy joints by TIG--CMT hybrid welding," Journal of Materials Processing Technology, vol. 255, pp. 161-174, 2018.

[19] L. Singh, R. Singh, N. K. Singh, D. Singh, and P. Singh, "An evaluation of TIG welding parametric influence on tensile strength of 5083 aluminium alloy," Int. J. Mech. Aerospace, Ind. Mechatronics Eng, vol. 7, no. 11, pp. 1262-1265, 2013.

[20] C. W. M. Noor, K. Samo, M. A. Musa, A. M. Muzathik, "The effect of Arc voltage and welding current on mechanical and micro structure properties of 5083-Aluminium Alloy joints used in marine applications," 2011.

[21] C. Prabaharan, P. Venkatachalam, K. Lenin, "Parametric Optimization of Gas tungsten arc welding processes by using factorial design approach," 2014.

[22] P. Mayur, K. M. Pavan, L. S. Sachin, C. A. Chandrashekar, and K. Ajay, "Effect of Welding Current on the Mechanical and Structural Properties of TIG Welded Aluminium Alloy AA-5083," International Journal of Mechanical Engineering and Research, vol. 3, pp. 431-438, 2013.

[23] B. J. Kutelu, S. O. Seidu, G. I. Eghabor, and A. I. Ibitoye, "Review of gtaw welding parameters," Journal of Minerals and Materials Characterization and Engineering, vol. 6, no. 5, pp. 541-554, 2018.

[24] I. P. Almanar, M. H. Hanapi, A. S. Anasyida, and Z. Hussain, "Friction Stir Welding of 6061-T6 Aluminum Alloy," in Advanced Materials Research, 2012, vol. 501, pp. 145-149.

[25] F. Yusof and M. F. Jamaluddin, "6.07 - Welding Defects and Implications on Welded Assemblies," in Comprehensive Materials Processing, S. Hashmi, G. F. Batalha, C. J. Van Tyne, and B. Yilbas, Eds. Oxford: Elsevier, 2014, pp. $125-134$.

[26] D. AWS, "1.2. 2004," Structural Welding Code-Aluminium.

[27] W. Woo and H. Choo, "Softening behaviour of friction stir welded Al 6061-T6 and Mg AZ31B alloys," Science and Technology of Welding and Joining, vol. 16, no. 3, pp. 267-272, 2011.

[28] M. Warmuzek, "Metallographic techniques for aluminum and its alloys," Materials Park, OH: ASM International, 2004., pp. 711-751, 2004.

[29] Y. Liu et al., "Microstructure and mechanical properties of aluminum 5083 weldments by gas tungsten arc and gas metal arc welding," Materials Science and Engineering: A, vol. 549, pp. 7-13, 2012.

[30] R. T. Wicaksono, S. Suharno, and B. Harjanto, "Pengaruh Kuat Arus Pada Pengelasan Paduan Aluminium 6061 Dengan Menggunakan Metode Las TIG Terhadap Kekerasan Dan Struktur Mikro," NOZEL Jurnal Pendidikan Teknik Mesin, vol. 1 , no. 1, pp. 29-36. 